\title{
ANALISIS STRATEGI HARGA DAN KUALITAS PELAYANAN TERHADAP KEPUASAN KONSUMEN CV HAPPY POLLY KARAOKE KELUARGA DI BANDAR LAMPUNG
}

\author{
Oleh: \\ Sophan Syaiful \\ Refki Irawan \\ Jurusan Manajemen, Universitas Mitra Indonesia \\ e-Mail : rachmatandfamily@gmail.com
}

\begin{abstract}
ABSTRAK
Penelitian ini bertujuan untuk dapat mengidentifikasi harga dan kualitas pelayanan terhadap kepuasan konsumen di CV Happy Polly Karaoke Keluarga Bandar Lampung.

Hasil penelitian menunjukan bahwa haga dan kualitas pelayanan sangat mempengaruhi kepuasan konsumen yang menggunakan jasa CVHappy Polly. Karena dari harga yang terjangkau maka konsumen sudah dapat menikmati pelayanan jasa yang ditawarkan dan mendapatkan pelayanan dari karyawan yang ramah dan membuat konsumen merasa dilayani dan puas menggunakan jasa CV Happy Polly
\end{abstract}

Kata kunci: strategi harga, kualitas pelayanan, kepuasan konsumen, CV Happy Polly

\section{ABSTRACT}

This study aims to identify the pricing and quality of service to customer satisfaction on $\mathrm{CV}$ Happy Polly Karaoke Keluarga Bandar Lampung

The results of the study showed that the pricing and service quality greatly influence the satisfaction of consumers who use the services of Happy Happy Polly. Because of the affordable price, consumers can enjoy the services offered and get services from employees who are friendly and make consumers feel served and satisfied using the services of CV Happy Polly.

Keywords: pricing strategy, serving quality, customer satisfaction, CV Happy Polly

\section{PENDAHULUAN}

\subsection{Latar Belakang Masalah}

Laju perekonomian dewasa ini membuat masyarakat memiliki aktivitas dan rutinitas yang cukup kompleks.Rutinitas tersebut membuat masyarakat merasa jenuh dan lelah. Hal tersebut pada akhirnya mendorong mereka untuk mengalihkan perhatian dan menciptakan suasana yang dapat membuat mereka lebih rileks. Kebutuhan untuk rileks tersebut terjawab dengan timbulnya bisnis hiburan yang sekarang banyak hadir ditengah masyarakat.Salah satu alternatif hiburan untuk masyarakat tersebut adalah 
karaoke.Tempat tersebut memungkinkan orang untuk sejenak melepaskan dan melupakan kejenuhannya dengan cara bernyanyi dan bersosialisasi dengan rekan atau kerabat. Perkembangannya yang pesat telah menjadikan karaoke sebagai trendlifestyle masa kini. Beragam konsep hiburan karaoke ditawarkan untuk menarik minat masyarakat salah satunya pada tempat karaoke dengan nama CV Happy Polly Karaoke.

CV Happy Polly yang merupakan salah satu tempat karaoke yang cukup digemari di Bandar lampung. CV Happy Polly Karaoke bertempat di Jalan Gajah Mada No. 28 D-E, Kota Baru, Tanjung Karang Timur, Kota Bandar Lampung. Hal yang mendasari penelitian ini dilakukan di CV Happy Polly Karaoke karena kualitas pelayanan yang disediakan masih belum sesuai dengan tempat karaoke tepat pada umumnya meskipun harga relatif lebih murah jika dibandingkan dengan tempat hiburan karaoke seperti Inul Vista, Pelangi Karaoke,dan NAV Karaoke. Hal tersebut ditunjukkan dari besarnya perbandingan tarif tempat hiburan karaoke yang disajikan pada tabel dibawah ini.

Berdasarkan observasi awal bahwa berkurangnya animo masyarakat untuk menggunakan jasa ini disebabkan semakinbanyaknya jasa hiburan lainnya yang dapat dinikmati selain jasa karaoke misalnya adanya beberapa cafeyang menawarkan jasa tempat nongkrong dengan suguhan live musik yang memberikan kesempatan kepada para tamunya untuk berpartisipasi dalam menyumbangkan sebuah lagu.

CV Happy Polly Karaoke merupakan tempat karaoke yang mengusung konsep tempat karaoke keluarga. Karaoke keluarga adalah tempat hiburan keluarga dimana pengunjung dapat bernyanyi bersama keluarga, teman-teman, teman kerja, relasi kerja dalam situasi kekeluargaan dan bersih serta sesuai dengan unsur dan normanorma yang berlaku di Indonesia. CV Happy Polly Karaoke ini terbuka untuk umum, hari biasa mulai pukul 11.00 - 23.00, sedangkan pada hari Sabtu dan Minggu tutup hingga pukul 02.00. CV Happy Polly Karaoke memiliki berbagai macam ukuran dengan harga sewadan fasilitas yang berbeda, yaitu Small room kapasitas 5 orang,Up Small room kapasitas 7 orang, dan kapasitas Medium room kapasitas10 orang

\subsection{Identifikasi Masalah}

1. Semakin banyaknya usaha hiburan yang menawarkan jasa tidak hanya terbatas pada tarik suara/vocal

2. Tingkat kepuasan pengunjung menurun yang ditunjukkan dari animo/keinginan masyarakat untuk menggunakan jasa karaoke mengalami penurunan sejak tahun 2015.

3. Kecakapan dan ketanggapan karyawan dalam melayani konsumen kurang memuaskan.

4.Harga yang relatif terjangkau ternyata belum mampu meningkatkan jumlah kunjungan konsumen.

5. Fasilitas lahan parkir yang tidak terlalu luas sehingga pengunjung sering kesulitan untuk memarkir kendaraan.

\subsection{Pembatasan Masalah}

Berdasarkan identifikasi masalah, peneliti memberikan batasan permasalahan agar dalam permasalahan dalam penelitian pembahasan dapat mencapai sasaran yang diharapkan. Berdasarkan hasil prasurvey yang menunjukkan bahwa kualitas pelayanan, harga dan kepuasan pelanggan menjadi faktor yang diduga mempengaruhi 
kepuasan pelanggan, maka peneliti membatasi masalah pada pengaruh kualitas pelayanan, harga, dan kepuasan pelanggan terhadap konsumen karaoke di CV Happy Polly Karaoke.

\subsection{Perumusan Masalah}

Berdasarkan identifikasi dan batasan masalah diatas maka rumusan masalah dalam penelitian ini yaitu:

1. Bagaimana pengaruh kualitas pelayanan terhadap kepuasan konsumen di CV Happy Polly Karaoke?

2. Bagaimana pengaruh harga terhadap kepuasan pelanggan karaoke di CVHappy Polly Karaoke?

3. Bagaimana pengaruh kualitas pelayanan, harga, dan kepuasan pelanggan secara simultan terhadap kepuasan konsumen karaoke di CV Happy Polly Karaoke?

\subsection{Pernyataan Penelitian}

Pada era globalisasi saat ini, keadaan perekonomian di Indonesia berkembang secara cepat dan pesat. Perkembangan perekonomian ditunjukkan semakin maraknya perusahaaan yang tumbuh, perusahaan- perusahaan tersebut bergerak dalam bidang yang berbeda- beda. Misalnya perusahaan manufaktur dan industri. Salah satu contoh perusahaan yang sedang berkembang di Indonesia adalah perusahaan yang bergerak dalam bidang jasa. Bidang jasa merupakan komponen yang tumbuh paling cepat, baik dalam perdagangan maupun investasi langsung luar negeri (foreign direct investment) (Tjiptono, 2006: 4). Salah satunya bidang jasa yang sedang berkembang saat ini adalah bidang jasa hiburan. Dewasa ini hiburan banyak dicari oleh masyarakat baik para pekerja maupun para pelajar, dengan tujuan untuk menghilangkan kepenatan, ketegangan, kejenuhan, dan rasa capek karena kegiatan rutinitas yang dilakukan setiap harinya. Dalam mengatasi hal tersebut, orang dapat mencari tempat hiburan yang menyenangkan hati, seperti taman hiburan, tempat wisata, bioskop, tempat karaoke, dan masih banyak tempat hiburan lainnya (Mariyanto, 2010).

Dewasa ini hiburan banyak dicari oleh masyarakat baik para pekerja maupun para pelajar, dengan tujuan untuk menghilangkan kepenatan, ketegangan,kejenuhan, dan rasa capek karena kegiatan rutinitas yang dilakukan setiapharinya. Dalam mengatasi hal tersebut, orang dapat mencari tempat hiburanyang menyenangkan hati seperti : taman hiburan, tempat wisata, bioskop,tempat karaoke, dan masih banyak tempat hiburan lainnya. Karena hiburanmerupakan salah satu kebutuhan yang tidak dapat dipisahkan dari kehidupanmanusia yang disebabkan adanya pola dan gaya hidup masyarakat yang semakin meningkat seiring dengan semakin berkembangnya perekonomian Indonesia.

Akhir-akhir ini semakin banyak berdirinya tempat-tempat hiburan khususnya karaoke yang menawarkan berbagai macam pelayanan dan fasilitas lengkap dengan teknologi modern untuk memanjakan konsumen disertai dengan penawaran paket harga yang bervariatif dan kompetitif. Dalam membeli suatu produk atau jasa, seorang konsumen mungkin mendeteksi adanya suatu kekurangan. Konsumen tidak menginginkan produk atau jasa, yang tidakmemenuhi standar mutu. Apa yang menentukan konsumen akan puas, atautidak puas tehadap suatu pembelian baik itu produk maupun jasa.

Kepuasan konsumen adalah fungsi seberapa dekat harapan konsumen atas suatu produk atau jasa dengan mutu yang dirasakan. Konsumen akan merasa tidak puas 
jikasuatu produk atau jasa tidak sesuai harapan, konsumen akan merasa puas jikasuatu produk atau jasa sesuai harapan, dan konsumen akan merasa sangat puas jika suatu produk atau jasa melebihi harapan

\subsection{Tujuan Penelitian}

a. Untuk mengetahui pengaruh harga terhadap kepuasan konsumen.

b. Untuk mengetahui pengaruh kualitas pelayanan terhadap kepuasan konsumen.

c. Kegunaan Penulisan Memberikan sumbangan pemikiran berupa kebijakan yang tepat bagi Karaoke Keluarga Happy Polly Bandar Lampung

\subsection{Kegunaan Penelitian}

\section{Secara Teoritis}

Penelitian ini diharapkan menjadi referensi untuk penelitian selanjutnya yang berhubungan dengan harga, kualitass pelayanan dan kepuaan konumen maupun penelitian yang sejenis. Selain itu juga dapat memberikan kontribusi bagi pengembangan teori administrasi pada kosentrasi manajemen pemasaran

\section{SecaraPraktis}

a. Bagi Peneliti

Penelitian ini digunakan untuk memenuhi tugas akhir skripsi sebagai persyaratan guna memperoleh Gelar Sarjana pada Jurusan Administrasi, Fakultas Fisip, Universitas Tulang Bawang Lampung.

Penelitian ini diharapkan menambah ilmu dan pengetahuan serta memberikan pemahaman tentang kualitas pelayanan, harga, dan kepuasan pelanggan dalam meningkatkan kepuasan konsumen.

b. Bagi Perusahaan

Hasil penelitian ini diharapkan dapat digunakan perusahaan sebagai bahan masukan maupun tambahan informasi tentang kualitas pelayanan, harga, dan kepuasan pelanggan dalam meningkatkan kepuasan konsumen.

\section{KAJIAN PUSTAKA}

\subsection{Harga}

\section{Pengertian Harga}

Harga adalah suatu nilai tukar dari produk barang atau pun jasa yang umumnya dinyatakan dalam satuan moneter (Rupiah, Dollar, Yen dll). Dari sudut pandang pemasaran, harga merupakan satuan moneter atau ukuran lainnya (termasuk barang dan jasa) yang dapat ditukarkan agar memperoleh hak kepemilikan atau penggunaan suatu barang atau jasa (Tjiptono, 2011).

\section{Tujuan Penetapan Harga}

Menurut Basu Swasta (2002:186) tujuan dari penetapan harga adalah:

a. Mendapatkan pengembalian investasi yang ditargetkan atau pengembalian pada penjualan bersih

b. Mencegah atau mengurangi persaingan

c. Mempertahankan atau memperbaiki market share

\section{d. Memaksimalkan laba}

Bagi produsen atau penjual, penetapan harga yang tepat pada produk akan berdampak pada besarnya keuntungan dan loyalitas konsumen. Mengacu pada pengertian harga di atas, adapun beberapa tujuan penetapan harga adalah sebagai berikut:

\section{Untuk Mendapatkan Pangsa Pasar}

Tujuan penetapan harga sangat berhubungan dengan target penjualan barang dan jasa. Sebagian bisnis menetapkan harga yang murah dan kualitas 
yang baik pada barang yang dijualnya dengan tujuan untuk mendapatkan pangsa pasar atau market share yang lebih besar.

Umumnya konsumen lebih memilih barang dengan harga yang murah dan kualitas terjamin. Namun produsen tentunya tetap memperhitungkan keuntungan dari penjualan tersebut.

\section{Meningkatkan Keuntungan}

Penetapan harga juga bertujuan untuk meningkatkan atau memaksimalkan keuntungan yang diperoleh. Semakin tinggi harga maka potensi keuntungan akan semakin besar. Namun tentu saja strategi penetapan harga harus memperhatikan daya beli konsumen, dan faktor- faktor lainnya.

\section{Menjaga Loyalitas Konsumen}

Penetapan harga dilakukan dengan berbagai pertimbangan, salah satunya adalah untuk menjaga loyalitas konsumen agar terus membeli dari produsen tertentu.

Tidak cukup hanya mendapatkan pangsa pasar, pebisnis juga harus menjaga loyalitas para konsumennya. Dan salah satu caranya adalah dengan menetapkan harga yang bersaing, yaitu harga yang murah dan kualitas produk yang baik.

\section{Menjaga Daya Saing}

Suatu perusahaan umumnya selalu berusaha untuk menjaga persaingan dengan para market leader atau pemimpin di pasar tertentu. Salah satu cara untuk menjaga daya saing dengan kompetitor adalah dengan penetapan harga yang tepat, misalnya menawarkan harga sedikit lebih murah atau memberikan harga yang sama dengan layanan tambahan.

\subsection{Kualitas Pelayanan}

\section{Pengertian Kualitas Harga}

Kualitas pelayanan adalah salah satu faktor yang mempengaruhi tingkat loyalitas pelanggan terhadap produk atau jasa. Perusahaan perlu meningkatkan kualitas layanan untuk mengembangkan loyalitas pelanggannya, karena produk atau jasa yang berkualitas rendah akan membuat pelanggan menjadi tidak setia. Artinya, dapat disimpulkan jika kualitas diperhatikan, maka loyalitas pelanggan akan lebih mudah diperoleh (Lupiyoadi, 2006). Parasuramanat al., (1998) kualitas pelayanan didefinisikan sebagai seberapa jauh perbedaan antara kenyataan dan harapan pelanggan atas layanan yang mereka terima atau peroleh. Sedangkan menurut Kotler (2009) bahwa kualitas pelayanan merupakan penilaian seseorang terhadap tempat atau lokasi, orang, peralatan, alat komunikasi dan harga yang mereka lihat sebelum mereka memutuskan untuk melakukan pembelian kembali di masa mendatang.

\subsection{Kepuasan Konsumen}

\section{Pengertian Kepuasan Konsumen}

Pada dasarnya tujuan dari suatu bisnis adalah untuk menciptakan konsumen yang merasa puas. Terciptanya kepuasan konsumen dapat memberikan beberapa manfaat antara lain pengaruh antara perusahaan dan konsumen menjadi harmonis, memberikan dasar yang baik bagi pembelian ulang dan terciptanya loyalitas konsumen, dan membentuk suatu rekomendasi dari mulut ke mulut (word ofmouth) yang menguntungkan bagi perusahaan.

Ada beberapa pakar yang memberikan definisi mengenai kepuasan atau ketidakpuasan konsumen. Kepuasan atau ketidakpuasan konsumen adalah respon konsumen terhadap evaluasi ketidak sesuaian (disconfirmation) yang dirasakan antara harapan sebelumnya (atau norma 
kinerja lainnya) dan kinerja aktual produk yang dirasakan setelah pemakaiannya.

Secara definitif dapat dikatakan bahwa kepuasan konsumen (Basu Swastha, 2000) adalah : "Suatu dorongan keinginan individu yang diarahkan pada tujuan untuk memperoleh kepuasan. Dalam hal ini kita perlu mengetahui bahwa suatu keinginan itu harus diciptakan atau didorong sebelum memenuhi motif. Sumber yang mendorong terciptanya suatu keinginan dapat berbeda dari diri orang itu sendiri atau berada pada lingkungannya.

Kotler (2001: 46) menandaskan bahwa kepuasan konsumen adalah tingkat perasaan seseorang setelah membandingkan kinerja (atau hasil) yang ia rasakan dibandingkan dengan harapannya. Bila kinerja melebihi harapan mereka akan merasa puas dan sebaliknya bila kinerja tidak sesuai harapan maka akan kecewa.

Pada dasarnya tujuan dari suatu bisnis adalah untuk menciptakan para konsumen yang merasa puas. Setiap orang atau organisasi (perusahaan) harus bekerja dengan konsumen internal dan eksternal untuk memenuhi kebutuhan mereka bekerjasama dengan pemasok internal dan eksternal demi terciptanya kepuasan konsumen. Terciptanya kepuasan konsumen dapat memberikan beberapa manfaat diantaranya (Tjiptono et al, 2003):

a. Hubungan perusahaan dengan konsumen menjadi harmonis.

b. Memberikan dasar yang baik bagi pembelian ulang.

c. Dapat mendorong terciptanya loyalitas konsumen.

d. Membentuk rekomendasi dari mulut ke mulut (word of mouth) yang menguntungkan perusahaan. e. Laba yang diperoleh meningkat.

\subsection{Kerangka Pikir}

Variabel yang dipergunakan dalam penelitian ini adalah variabel harga, kualitas pelayanan sebagai variabel bebas, sedangkan variabel dependennya adalah kepuasan konsumen. Hubungan antara variabel secara skematik dapet dilihat pada gambar berikut ini.

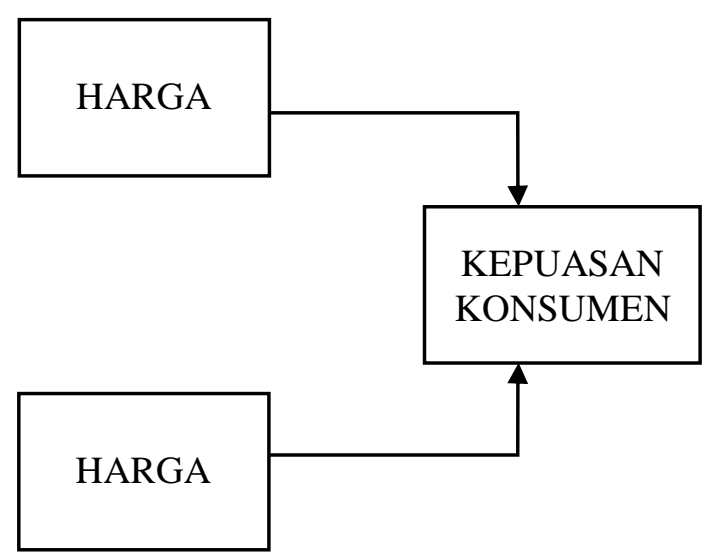

Gambar 1.1. Kerangka Pemikiran

\section{METODE PENELITIAN}

Peneltian ini dilakukan di CV Happy Polly Karaoke beralamat di Jalan Gajah Mada No. 28 D- E, Kota Baru, Tanjung Karang Timur, Kota Bandar Lampung. Lokasi penelitian dilakukan secara sengaja (Purposive) dengan mempertimbangkan kelengkapan dan kemudahan data yang didapat serta kegiatan penelitian ini dilakukan pada bulan Februari-Maret 2017.

\subsection{Jenis dan Sifat Penelitian}

\section{Sifat Penelitian}

Dilihat dari segi sifatnya, penelitian ini adalah penelitian deskriptif, artinya penelitian yang menggambarkan objek tertentu dan menjelaskan hal- hal yang terkait dengan atau melukiskan secara sistematis fakta-fakta atau karakteristik populasi tertentu dalam bidang tertentu secara factual dan cermat. 
a. Penelitian ini bersifat deskriptif karena penelitian ini semata-mata menggambarkan suatu objek untuk menggambil kesimpulankesimpulan yang berlaku secara umum.

b. Dalam penelitian ini penulis akan mendekripsikan penelitian ini berkaitan dengan gerakan dakwah Jama'ah Tabligh di kalangan wanita dengan menggunakan metode khurûj fî̀ sabîlillâh dalam pembinaan keluarga Muslim di kota Bandar Lampung.

\section{Jenis Penelitian}

Penelitian ini adalah jenis penelitian adalah menggunakan pendekatan kualitatif sebagai metodologi penelitiannya, yakni penelitian yang bertujuan untuk menjalankan fenomena melalui pengeumpulan data sedalam- dalamnya.3 Penelitian kualitatif tidak selalu bertujuan untuk mencari sebab akibat terjadinya sesuatu, tetapi lebih berupaya memahami situasi tertentu untuk sampai pada suatu kesimpulan objektif, penelitian kualitatif berupaya mendalami dan menerobos gejalanya dengan menginterprestasikan masalah atau menyimpulkan kombinasi dari berbgai arti permasalahan sebagaimana disajikan oleh situasinya.

\subsection{Sumber data}

Data yang digunakan pada penelitian ini terdiri dari data primer dan data skunder

Data primer dan Data skunder merupakan sumber-sumber data informasi yang dikumpulkan untuk menjadi dasar kesimpulan dari sebuah penelitian. Meskipun pada hakiktnya pengertian keduanya sama-sama merupakan sumber data, namun berbeda cara memperoleh

a. Data primer data diperoleh dari pengamatan lansung dilapangan, berupa data hasil wawancara dan pengisian kuisioner responden pilihan.
Responden adalah pihak perusahaan yang terkait dengan penerapan promosi $\mathrm{CV}$ Happy Polly Karaoke di wilayah Bandar Lampung.

Kelebihan dari data primer adalah data lebih mencerminkan kebenaran berdasarkan dengan apa yang dilihat dan didengar langsung peneliti.

Kekurangan dari data primer adalah membutuhkan waktu yang relative lama.

b. Data sekunder merupakan data pelengkap dari data primer, yaitu data-data yang didapat dari instansi terkait. Data sekunder ini juga diperoleh dari data yang dimiliki oleh perusahaan seperti gambaran umum perusahaan dan dokumen perusahaan, internet, dan lainnya.

Kelehihan dari data sekunder adalah waktu dan biaya yang dibutuhkan untuk penelitian untuk mengklarifikasi permasalahan dan mengevaluasi data, relatif lebih sedikit dibandingkan dengan pengumpulan data terjadi primer.

Kekurangan dari data sekunder adalah jika sumber data terjadi kesalahan, kadaluarsa atau sudah tidak relevan dapat mempengaruhi hasil penelitian.

\subsection{Teknik Pengumpulan Data}

\section{Teknik Penelitian Lapangan}

Penelitian lapangan untuk melihat secara langsung objek penelitian serta mengumpulkan data yang diperlukan dalam analisis. Adapun penelitian lapangan yang dilakukan adalah meliputi

a. Teknik Angket (Kuesioner)

Yaitu dengan mengajukan pertanyaan langsung kepada seorang informan atau seorang autoritas yang berwenang di CV Happy Polly Karaoke untuk menggali data 
sesuai dengan topic dan pengumpulan data dilapangan yang dibutuhkan oleh penulis.

\section{b. Teknik Observasi}

Yaitu dengan melakukan pengamatan lansung terhadap kegiatan promosi $\mathrm{CV}$ Happy Polly dilapangan. Penulis dapat secara langsung mengamati, melihat, mendengar, keadaan langsung di lapangan.

\section{Teknik Wawancara}

Wawancara dilakukan melalui metode pengumpulan data dengan cara tanya jawab sepihak dan berhadapan langsung dengan pihak manajemen happy polly karaoke Bandar Lampung.

\section{Teknik Dokumentasi}

Pengumpulan data melalui permintaan keterangan kepada pihak manajemen happy polly karaoke Bandar Lampung dengan cara mengajukan pertanyaan-pertanyaan secara tersusun dalam daftar sehingga akan diperoleh jawaban- jawaban dan pertanyaan yang diajukan.

\subsection{Penentuan Key Informasi dan Informan}

Key Informan adalah narasumer kunci atau utama yang paling banyak tahu sesuatu informasi (Data) mengenai hal yang diteliti. Sedangkan informan adalah seorang narasumber biasa atau anggota kelompok yang diriset yang diharapkan mempunyai berbagai informasi penting. Sehingga penulis memilih key informan berdasarkan karakteristik yang dianggap memliki informasi yang relevan.

\subsection{Teknik Analisis Data}

Analisis data dalam penelitian ini dilakukan ecara kualitatif, yaitu dimulai dari lapangan atau fakta empiris yang diperoleh dengan cara terjun kelapangan. Adapun langkah- langkah yang dilakukan adalah sebagai berikut:

\section{a. Pengumpulan Data}

Penelitian dilakukan dengan mencatat semua data secara objektif dan apa adanya sesuai dengan observasi dan wawancara dilapangan. Pengumpulan data diperoleh melalui observasi dan wawancara dengan para konsumen yang menggunakan jasa hiburan CV Happy Polly Karaoke.

\section{b. Penyajian Data}

Penyajian data adalah sekumpulan informasi tersusun yang memberikan kemungkinan adanya penarikan kesimpulan dan pengambilan tindakan. Kegiatan ini dilakukan oleh peneliti dengan cara hasil dari redukasi yang sudah sering digunakan konsumen di kalangan keluarga dalam memilih hiburan/jasa CV Happy Polly karaoke di Bandar lampung.

\section{c. Analisis Kualitatif}

Yaitu analisa pengaruh harga dengan menggunakan teori dan kualitas pelayanan pendekatan-pendekatan yang berhubungan dengan terhadap kepuasan konsumen.

\section{d. Analisis Hasil Penelitian}

Asumsi-asumsi yang digunakan dalam penulisan ini adalah :

1. Peraturan pemerintah yang berkenan dengan sektor hiburan menguntungkan pengusaha hiburan karaoke.

2. Kondisi sosial politik di Propinsi Lampung yang kondusif yang dapat menciptakan rasa aman bagi para konsumen, baik asing maupun domestik.

3. Perkembangan pengaruh harga dan kualitas pelayanan terhadap kepuasan konsumen relatif lebih cepat dari tingkat pertumbuhan ekonomi, maka perekonomian diabaikan. 


\section{e. Sistematika Penulisan}

Penulisan ini terbagi dalam lima bagian dengan sistematika sebagai berikut:

Bagian Pertama: Merupakan pendahuluan yang memaparkan runtunan penelitianpenelitian. Dalam masalah yang dihadapi, sehingga masalah dalam penulisan ini jelas dan wajar untuk di teliti. Bagian pertama ini memberikan dasar pijakan untuk bagian selanjutnya.

Bagian Kedua: Berisikan landasan teori yang berkaitan dengan masalah yang akan diteliti. Teori memberikan gambaran seperti yang telah dipaparkan dalam kerangka bagian pertama.

Bagian Ketiga: Berkaitan dengan gambaran umum perusahaan, yaitu pengungkapan tentang keadaan perusahaan tempat penelitian dilakukan.

Bagian Keempat: Berisikan analisa dan pembahasan masalah yang terdapat pada bagian pertama.

Bagian Kelima: Berisi kesimpulan dan saran dari keseluruhan tulisan ini simpulan disesuaikan dengan tujuan penulisan dan berdasarkan simpulan yang diperoleh dirumuskan saran yang dapat dijadikan bahan pertimbangan bagi pimpinan perusahaan tempat penulis melakukan penelitian.

\subsection{Uji Keabsahan Data}

Dalam penelitian ini pemeriksaan keabsahan data sangat diperlukan adalah penelitian kualitatif demi kesahihan dan kehandalan serta tingkat kepercayaan data yang terkumpul. Penelitian ini menggunakan teknik menguji dan memastikan temuan melalui memeriksa kerepresentatifan yakni aspek pilihan informan yang mewakili masalah yang diteliti, memeriksa pengaruh peneliti, member bobot pada bukti, membuat perbandingan atau pertentangan, membuat replica temuan mencari penjelasan tandingan, serta teknik terakhir adalah mendapatkan umpan balik key informan.

Melalui Teknik pemeriksaan ini, penulis menggunaka teknik triagulasi data dan triagulasi teori, dimana data dikumpulkan serta dikaitkan juga dengan teori-teori dari terlaksananya seluruh kegiatan strategi kualitas pelayanan konsumen dari CV Happy Polly Karaoke yakni fakta data, dan informasi yang didapat dipertanggung jawabkan dan memenuhi persyaratan kesahihan dan kehandalan.

Pemeriksaan dan pengecekkan dilakukan peneliti pada penelitian ini melalui sumber lain yaitu dengan cara membandingkan data hasil pengamatan dan hasil wawancara dengan key informan.

\section{HASIL PENELITIAN PEMBAHASAN}

4.1. Hasil Penelitian

CV Happy Polly Karaoke Keluarga menghadapi persaingan yang cukup ketat dari para pesaing dalam segi harga dan kualitas pelayanan konsumen. Pelaksanaan kegiatan di CV Happy Polly Karaoke Keluarga menerapkan strategi yang dapat menguntungkan perusahaan maupun konsumen, agar dapat mendapatkan citra untuk perusahaan dan menguntungkan bagi konsumen supaya konsumen tersebut mendapatkan yang terbaik didalam jasa hiburan.

Adapun strategi yang diterapkan pada CV Happy Polly Karaoke Keluarga diantaranya adalah:

1. Promosi

2. Harga

3. Kualitas Pelayanan 


\section{KESIMPULAN DAN SARAN}

\subsection{Kesimpulan}

Berdasarkan hasil penelitian dan pembahasan, maka dapat ditarik beberapa kesimpulan sebagai berikut:

1. Penentuan harga sangat mempengaruhi atas kepuasan konsumen karena dari penetapan harga yang tepat sasaran yang akan menimbulkan keinginan untuk menggunakan jasa Happy Poly.

2. Kualitas Pelayanan juga berpengaruh terhadap kepuasan konsumen karena selain harga yang terjangkau konsumen juga sangat memperhatikan kualitas pelayanan dari sebuah perusahaan jasa. Apabila pelayanan baik maka konsumen pun merasa puas.

3. Konsumen Happy Poly Karaoke merasa puas dengan harga dan pelayanan yang di tetapkan di Happy Poly Karaoke Jalan Gajah Mada Bandar Lampung.

\subsection{Saran}

Berdasarkan hasil penelitian, pembahasan dan kesimpulan yangdiperoleh, maka saran yang dapat diberikan sebagai berikut:

1. Bagi Happy Polly Karaoke Hasil penelitian diketahui bahwa variabel kualitas pelayanan memiliki pengaruh yang lebih kecil dibandingkan variabel fasilitas dan harga dalam memengaruhi kepuasan pelanggan karaoke di Happy Polly Karaoke. Oleh karena itu, hendaknya pihak pengelola Happy Polly Karaoke meningkatkan kualitas pelayanan dalam hal menerima tamu supaya lebih cekatan sehingga pelanggan karaoke tidak menunggu terlalu lama untuk masuk ke ruangan yang sudah dipesan. Apabila kualitas pelayan ditingkatkan secara otomatis minat konsumen untuk menggunkan jasa hiburan karaoke Happy Poli akan meningkat.
2. Menggunakan metode lain dalam meneliti kepuasan pelanggan, misalnya melalui wawancara mendalam terhadapkonsumen, sehingga informasi yang diperoleh dapat lebih bervariasidaripada angket yang jawabannya telah tersedia.

\section{DAFTAR PUSTAKA}

Adrian, Payne. (2000). The Essence of Services Marketing. Alih Bahasa, Fandy. Tjiptono - Edisi II Yogyakarta: Andi.

Alfabeta.Amir. (2005). Dinamika Pemasaran: Jelajahi \& Rasakan. Jakarta: PT. RajaGrafindo Persada.

Basu Swastha. (2002). Manajemen Pemasaran. Jakarta: Penerbit Liberty.

Cahyo Wahyuno. (2013). Pengaruh Harga Terhadap Kepuasan Konsumen Di Hotel Anugerah Glagah Indah. Jurnal. UNY.

Engel, James, F, Roger D. Blackwell, dan Paul W. Miniard. (1994). Perilaku Konsumen. Edisi Keenam. Jilid 1. Jakarta: Penerbit Binarupa Aksara.

Fatchur Rachman. (2014). Pengaruh Kualitas Layanan, Harga, dan Lokasi terhadap Kepuasan Pelanggan Auto 2000 Sungkono Surabaya. Jurnal.UNY.

Hadi, Sutrisno. (2004). Metodologi Research Jilid 3. Yogyakarta: Andi.

Hazewinkel, Michiel ed. (2001). "Kolmogorov-Smirnov test", Encyclopedia of Mathematics. Springer, ISBN 978-1-55608-010-4.

Juwandi, Hendy Irawan. 2004. Kepuasan Pelayanan Jasa. Erlangga. Jakarta. 
Kartajaya, Hermawan. (2006). Marketing

Mix. Jakarta: PT. Gramedia

PustakaUmum.

Kotler dan Keller. (2007). Manajemen Pemasaran. Jakarta: PT. Indeks.

Kotler, Philip. 2001. Manajemen Pemasaran di Indonesia : Analisis, Perencanaan, Implementasi dan Pengendalian. Salemba Empat. Jakarta.

Kumar, Ranjit. (2005). Research Methodology: A step by step guide forbeginners. Second. London : SAGE Publication Ltd. p. 153.[35].

Kuncoro Mudrajad. (2003). Metode Riset untuk Bisnis dan Ekonomi. Jakarta:Erlangga.

Laila, dkk. (2012). Pengaruh Kualitas Pelayanan, Harga dan Nilai Pelanggan terhadap Kepuasan Pelanggan Pengguna Jasa Servis Bengkel AHASS 0002 Semarang Honda Center. Jurnal Jurusan Manajemen

Fakultas Ekonomi.Universitas Pandanaran Semarang.

Lupiyoadi, Rambat. (2001). Manajemen Pemasaran Jasa (Teori dan Praktik). Jakarta: Salemba Empat.

Lupiyoadi, Rambat dan Hamdani, A. 2001. Manajemen Pemasaran Jasa. Salemba Empat. Jakarta.

Nasution. (2004). Total Quality Management. Jakarta: PT Gramedia PustakaUtama.

(2005). Total Quality Management. Jakarta: PT Gramedia PustakaUtama.
Peter dan Olson. (1996). Perilaku Konsumen dan Strategi Pemasaran. Jakarta:Gelora Aksara Pratama.

Steffi Mongkaren. (2013). Pengaruh Fasilitas dan Kualitas Pelayanan Terhadap Kepuasan Pelanggan Rumah Sakit Advent Manado. Jurnal. UNY.

Sugiyono. 2012. Metode Penelitian Bisnis. Bandung: Alfabeta.

Sumarwan, Ujang. (2003). Perilaku Konsumen. Jakarta: Penerbit Ghalia Indonesia.

Suryani, Tatik. (2008). Perilaku Konsumen. Yogyakarta: Graha Ilmu.

Tse dan Wilson. (2004). Manajemen Jasa Terpadu. Ghalia Indonesia.

Umar, Husein. (2005). Riset Sumber Daya Manusia. Jakarta: Gramedia Pustaka Utama.

Wisnalmawati. (2005). Pengaruh Persepsi Dimensi Kualitas Layanan Terhadap Niat pembelian Ulang. Jurnal Ekonomi dan Bisnis, No. 3 Jilid 10 2005, h. 153-165.

Yuda Supriyanto. (2012). Analisis Pengaruh Kualitas Pelayanan, Harga, dan Fasilitas Terhadap Kepuasan Pasien Rawat Jalan di Rumah Sakit Kariadi Semarang. Jurnal Manajemen. Universitas Diponegoro.

Zeithaml, Valerie, A., and Bitner, Mary Jo. (1996). Marketing. Singapore: McGrow Hill. 